\title{
PERAN PENYULUH PERTANIAN DALAM PENERAPAN BUDIDAYA PADI ORGANIK DENGAN METODE SRI (SYSTEM RICE OF INTENSIFICATION) DI KOTA TARAKAN
}

\author{
Rayhana Jafar ${ }^{1}$, Sulton Alimin ${ }^{2}$ \\ 1,2 Dosen Universitas Borneo Tarakan, Fakultas Pertanian, Program Studi Agribisnis \\ Jl. Amal Lama no 1, Tarakan Timur, Tarakan. \\ E-Mail: rayhanajafar@gmail.com
}

Received: 12 July 2019 Accepted: 20 September 2019

\begin{abstract}
Counseling is one of the important things in providing knowledge to farmers as a process of disseminating information, information processes or providing explanations, the process of changing farmers' behavior (attitudes, knowledge and skills) and the educational process. The importance of the role of agricultural extension workers, especially in the application of organic rice cultivation using the SRI (System of Rice Intensification) method in Tarakan City is still very much needed to improve human resources (farmers) so that they are able to manage existing natural resources intensively in order to achieve productivity and income improvement activities. The purpose of this study was to describe the role of agricultural extension agents in the application of the SRI method in the Mamburungan Village of Tarakan City and to find out the obstacles faced by agricultural extension workers in extension activities to farmer groups in Mamburungan Village, Tarakan City. This research is a qualitative descriptive study with a survey method. This research is analyzed by using descriptive analysis and Likert Scale. Determination of samples using purposive sampling technique. The results of the study show the role of agricultural instructors in the application of the SRI method in Mapan Sejahtera farmer groups as facilitators, motivators, educators and communicators are categorized as very important. The obstacle faced by extension agents in conducting extension activities is the lack of farmers' participation in developing organic rice cultivation with the SRI system because farmers are still focused on conventional rice cultivation; facilities and infrastructure in conducting extension activities are still very minimal so that the process of extension activities is hampered.
\end{abstract}

Key words: Extension, Role of Extension, SRI Method

\begin{abstract}
ABSTRAK
Penyuluhan merupakan salah satu hal yang penting dalam memberikan pengetahuan kepada para petani sebagai proses penyebarluasan informasi, proses penerangan atau memberikan penjelasan, proses perubahan prilaku petani (sikap, pengetahuan dan keterampilan) dan proses pendidikan. Pentingnya peran penyuluh pertanian khususnya dalam penerapan budidaya padi organik dengan metode SRI (System of Rice Intensification) di Kota Tarakan masih sangat dibutuhkan untuk meningkatkan SDM (petani) sehingga mampu mengelola sumber daya alam yang ada secara intensif demi tercapainya kegiatan peningkatan produktivitas dan pendapatan. Tujuan penelitian ini adalah untuk mendeskripsikan peran penyuluh pertanian dalam penerapan metode SRI di Kelurahan Mamburungan Kota Tarakan dan mengetahui kendala yang dihadapi oleh penyuluh pertanian dalam kegiatan penyuluhan pada kelompok tani di Kelurahan Mamburungan Kota Tarakan. Penelitian ini adalah penelitian deskriptif kualitatif dengan metode survei. Metode analisis data yang digunakan adalah deskriptif dan Skala Likert. Penentuan sampel dengan menggunakan teknik purposive sampling. Hasil penelitian menunjukkan peran penyuluh pertanian dalam penerapan metode SRI di kelompok tani Mapan Sejahtera sebagai fasilitator, motivator, edukator dan komunikator dikategorikan sangat berperan. Kendala yang dihadapi penyuluh dalam melakukan kegiatan penyuluhan adalah kurangnya partisipasi petani dalam pengembangan budidaya padi organik dengan sistem SRI karena petani masih terfokus dengan budidaya padi secara konvensional; sarana dan prasarana dalam melakukan kegiatan penyuluhan masih sangat minim sehingga mengakibatkan proses kegiatan penyuluhan terhambat.
\end{abstract}

Kata kunci: Penyuluh, Peran Penyuluh, Metode SRI (System of Rice Intensification) 


\section{PENDAHULUAN}

Pembangunan pertanian di Indonesia diarahkan pada sistem pertanian yang berwawasan lingkungan, berdaya saing tinggi, berkelanjutan, berkerakyatan dan terdesentraslisasi menuju pertanian yang mandiri, maju dan sejahtera. Salah satu sistem pertanian yang berkelanjutan dan berwawasan lingkungan adalah sistem pertanian organik, dimana di Indonesia sistem pertanian tersebut mulai diusahakan tidak hanya untuk memenuhi kebutuhan lokal tetapi juga diarahkan untuk memenuhi permintaan pasar global. Menurut IFOAM (2005), pertanian organik merupakan suatu pendekatan sistem yang utuh berdasarkan satu perangkat proses yang menghasilkan ekosistem yang berkelanjutan (sustainable), pangan yang aman, gizi yang baik, kesejahteraan hewan dan keadilan sosial. Pertanian organik bukan saja menghasilkan produk yang berkualitas, tetapi juga berwawasan lingkungan dan mempertimbangan faktor ekonomi, sosial dan budaya termasuk kearifan lokal

Menurut Departemen Pertanian, padi merupakan salah satu komoditas tanaman pangan yang prospektif untuk dikembangkan secara organik. Salah satu program yang dibentuk oleh pemerintah dalam pengembangan sistem pertanian organik yang berkelanjutan adalah metode SRI (System of Rice Intensification) yang bertujuan untuk mengefesienkan biaya-biaya yang dikeluarkan oleh petani dalam usahataninya yang ramah lingkungan dan berkelanjutan. Kota Tarakan khususnya di Kelurahan Mamburungan menerapkan sistem pertanian organik dengan metode SRI untuk memperoleh kecukupan pangan ditingkat rumah tangga, memberikan pangan berkualitas sekaligus memperbaiki kualitas tanah, memperbaiki keanekaragaman hayati yang ada disekitar.

Pengembangan usahatani padi membutuhkan teknologi untuk meningkatkan produksi dan produktivitasnya, meningkatkan efisiensi usaha, menaikkan nilai tambah produk yang dihasilkan serta meningkatkan pendapatan petani. Menurut Mosher (1996) dalam Mangunwidjaja, Sailah (2009) mengemukakan bahwa salah satu syarat mutlak pembangunan pertanian adalah adanya teknologi usahatani yang senantiasa berubah. Oleh sebab itu penggunaan teknologi dalam usahatani padi sangat dibutuhkan oleh petani. Selain penggunaan teknologi, peran penyuluh sangat diperlukan untuk memberi pengetahuan kepada petani tentang pertanian organik dengan metode
SRI sehingga dapat meningkatkan produktivitas usahataninya dan meningkatkan pendapatan guna mewujudkan kesejahteraan petani.

Penyuluhan pertanian menurut Undangundang Republik Indonesia Nomor 16 Tahun 2006 tentang Sistem Penyuluhan Pertanian, Perikanan dan Kehutanan (UU SP3K), adalah proses pembelajaran bagi pelaku utama serta pelaku usaha agar mereka mau dan mampu menolong dan mengorganisasikan dirinya dalam mengakses informasi pasar, teknologi, permodalan dan sumber daya lainnya, sebagai upaya untuk meningkatkan produktivitas, efesiensi usaha, pendapatan dan kesejahteraannya serta meningkatkan kesadaran dalam pelestarian fungsi lingkungan hidup.

Dalam kegiatan penyuluhan pertanian, penyuluh memegang peranan penting dalam proses pembelajaran, penyampaian kebijakan dari pemerintah dan penerapan teknologi yang dibutuhkan oleh petani. Hal yang penting dalam sistem penyuluhan pertanian adalah pengembangan sumber daya manusia, baik pada kelompok-kelompok, wanita pedesaan, pemuda desa, maupun petani kecil pada umumnya (Hariadi, 2011). Peran penyuluh dalam membentuk dan mengembangkan kelompokkelompok tani sebagai wadah belajar dan kerjasama dengan beragam kegiatan dibidang pertanian. Pendekatan kelompok yang merupakan pendekatan secara sosial ekonomi dilakukan oleh penyuluh pertanian karena keterbatasan sumberdaya (modal usaha, lahan pertanian, dan sebagainya) yang dimiliki oleh petani secara individual. Sedangkan secara sosial budaya pendekatan ini dilakukan karena masyarakat Indonesia khususnya di kota Tarakan yang memiliki ragam budaya, adat istiadat dan kebanyakan orientasi pada kelompok dalam setiap kehidupannya.

Program SRI yang merupakan salahsatu program pemerintah di Kota Tarakan Kelurahan Mamburungan, tidak luput dari adanya peran Penyuluh Pertanian Lapangan (PPL) yang berada di Dinas Pangan, Pertanian dan Perikanan. Tercapainya program tersebut merupakan faktor yang mempengaruhi keberhasilan sistem SRI melalui peran penyuluh. Usahatani padi organik metode SRI diwilayah Kelurahan Mamburungan pada Kelompok Tani Mapan Sejahtera dalam pelaksanaannya masih banyak hambatan yang dihadapi. Hambatan tersebut diantaranya masih sulit mengubah pola piker petani untuk mengubah budidaya padi konvensional menuju organik serta masih minimnya sarana dan 
prasarana yang menunjang kegiatan penyuluhan tentang metode SRI. Hutagaol dan Hartoyo (2013), mengatakan bahwa pemahaman petani tentang pertanian organik, terdapat beberapa variasi pemahaman petani mengenai pertanian organik tersebut. Ada petani yang memahami dan mempunyai keinginan berpindah ke pertanian organik dan masih ada pula petani yang bertahan dengan pertanian yang konvensional.

Berdasarkan uraian diatas, penenilitian ini bertujuan untuk mendeskripsikan peran penyuluh pertanian dalam penerapan metode SRI di Kelurahan Mamburungan Kota Tarakan dan mengetahui kendala yang dihadapi oleh penyuluh pertanian dalam kegiatan penyuluhan pada kelompok tani di Kelurahan Mamburungan Kota Tarakan.

\section{Lokasi Penelitian}

\section{BAHAN DAN METODE}

Penelitian ini dilakukan di Kelompok Tani Mapan Sejahtera Kelurahan Mamburungan Kecamatan Tarakan Timur Kota Tarakan dengan pertimbangan bahwa Kelompok Tani Mapan Sejahtera merupakan kelompok tani yang menerapkan sistem SRI dalam budidaya padi organik di Kota Tarakan.

\section{Metode}

Penentuan sampel dilakukan secara Purposive Sampling dengan pertimbangan tertentu sesuai kriteria responden yaitu aktif dalam kegiatan kelompok tani dan menerapkan metode SRI dalam budidaya padi. Sebanyak 13 orang petani padi organik. Wawancara juga dilakukan dengan Penyuluh Pertanian Lapangan (PPL) untuk memperdalam informasi yang berhubungan dengan tujuan penelitian. Jenis data yang digunakan dalam penelitian ini meliputi data primer dan sekunder. Data primer diperoleh melalui wawancara dengan empat belas orang responden yang terdiri dari petani dan Penyuluh Pertanian Lapangan (PPL). Data sekunder diperoleh dari berbagai literatur yang berkaitan dengan topik penelitian sumber seperti data dari BPS kota Tarakan serta data penunjang lainnya dari internet, artikel ilmiah, media cetak dan penelitian terdahulu.

\section{Analisis Data}

Metode analisis data yang digunakan dalam penelitian ini adalah deskriptif dan Skala Likert. Analisis deskriptif digunakan untuk mendeskripsikan peran dan kendala yang dihadapi penyuluh pertanian dengan melihat dan memberi gambaran serta menjelaskan keadaan/kondisi nyata melalui wawancara mendalam dengan responden. Data yang diperoleh kemudian dianalisis dengan menggunakan Skala Likert. Kriteria penilaian untuk setiap kategori peran penyuluh sebagai fasilitator, edukator, motivator dan komunikator masing-masing adalah 3 = sangat berperan, $2=$ berperan, dan $1=$ tidak berperan.

\section{HASIL DAN PEMBAHASAN Profil Kelompok Tani Mapan Sejahtera}

Kelompok Tani Mapan Sejahtera merupakan salah satu kelompok tani yang berada di Kelurahan Mamburungan Kecamatan Tarakan Timur Kota Tarakan, Provinsi Kalimantan Utara yang beralamat di Jl. Sei Sembakung RT.07 dan mulai berdiri dari tahun 2007. Luas lahan yang dimiliki Kelompok Tani Mapan

Sejahtera seluas 15 ha yang dimanfaatkan untuk kegiatan di bidang pertanian tanaman pangan dan hortikultura. Jenis tanaman yang diusahakan antara lain tanaman pangan (padi, jagung, singkong) dan Hortikultura (buahbuahan dan berbagai jenis tanaman sayur). Susunan pengelolah Kelompok Tani Mapan Sejahtera :
a. Ketua
b. Sekretaris
: Muhammad Alis
c. Bendahara
: Syarifudin
d. Jumlah anggota
: Rusli

Peran Penyuluh Pertanian Dalam

Penerapan Sistem SRI Padi Organik di Kelurahan Mamburungan Kota Tarakan. Pengembangan kelompok tani diarahkan pada peningkatan kemampuan kelompok, peningkatan kemampuan para anggota kelompok tani menjadi organisasi yang kuat dan mandiri. Peran penyuluh dalam penerapan budidaya padi organik di kelompok tani Mapan Sejahtera Kelurahan Mamburungan meliputi peran fasilitator, motivator, edukator dan komunikator. Peran penyuluh dalam penerapan budidaya padi organik dengan metode SRI di kelompok tani masih ada kendalanya diantaranya dapat dilihat dari indikator peran penyuluh pertanian lapangan sebagai berikut:

\section{Peran Penyuluh Sebagai Fasilitator}

Peran fasilitator dalam suatu program sangat di perlukan bagi petani. Fasilitator sebagai seseorang yang memfasilitasi pelaksanaan kegiatan program juga memiliki peran lain dalam mendukung keberhasilan program. Peran fasilitator tersebut membantu petani dalam mengoptimalkan segala kegiatan yang dilakukan dalam rangka memajukan program. Bukan hanya itu, fasilitator memiliki peran yang sangat di 
perlukan bagi masyarakat baik dalam memecahkan masalah yang dihadapi petani, pemberi informasi maupun sebagai seseorang yang mendampingi sekaligus melatih masyarakat untuk mengembangkan potensi dan memiliki pengetahuan serta keterampilan (Kowiyah, 2012).

Hasil pengukuran menunjukan bahwa penyuluh sangat berperan dalam menjalankan tugasnya sebagai fasilitator. Skor yang diperoleh penyuluh sebagai fasilitator terdapat pada Tabel 1 berikut.

Tabel 1. Kategori Peran Penyuluh Sebagai Fasilitator

\begin{tabular}{lll}
\hline Fasilitator untuk & Nilai \\
\hline $\begin{array}{l}\text { Membantu petani } \\
\text { mendapatkan saprodi }\end{array}$ & 39 \\
\hline $\begin{array}{l}\text { Membantu petani untuk mendirikan } \\
\text { dan mengembangkan kelompok tani }\end{array}$ & 39 \\
\hline $\begin{array}{l}\text { Membantu kelompok untuk } \\
\text { mendapatkan akses dengan Dinas }\end{array}$ & 39 \\
Pertanian & 117 \\
\hline Total Nilai & $\begin{array}{l}\text { Sangat } \\
\text { Kategori }\end{array}$ \\
\hline
\end{tabular}

Sumber : Analisis Data Primer, 2019

Berdasarkan tabel diatas dapat diketahui bahwa peran penyuluh sebagai fasilitator adalah sangat berperan, dengan perolehan skor 117 . Petani responden yang menyatakan penyuluh sangat berperan dalam membantu mendapatkan saprodi, mendirikan dan mengembangkan kelompok tani dan mendapatkan akses dengan Dinas Pertanian.

\section{Peran Penyuluh Sebagai Motivator}

Peran penyuluh pertanian sebagai motivator dalam kinerja kelompok tani merupakan tugas yang diharapkan dapat dijalankan penyuluh pertanian dalam membangkitkan semangat petani dan mempengaruhi petani agar tergerak untuk berpartisipasi dalam kegiatan usahatani. Skor yang diperoleh penyuluh sebagai motivator terdapat pada Tabel 2.

Tabel 2. Kategori Peran Penyuluh Sebagai Motivator

\begin{tabular}{ll}
\hline Motivator Nilai \\
\hline $\begin{array}{l}\text { Mendorong petani untuk berinovasi } \\
\text { (menciptakan hal-hal/ide baru) }\end{array}$ & 39 \\
\hline $\begin{array}{l}\text { Mendorong petani untuk } \\
\text { meningkatkan keterampilan dalam } \\
\text { berwirausaha }\end{array}$ & 32 \\
\hline $\begin{array}{l}\text { Mendorong petani untuk mau } \\
\text { menggunakan kemudahan teknologi } \\
\text { dalam berusaha tani }\end{array}$ & 37 \\
\hline Total Nilai & 108 \\
\hline Kategori & $\begin{array}{l}\text { Sangat } \\
\text { Berperan }\end{array}$ \\
\hline
\end{tabular}

Berdasarkan Tabel diatas dapat dilihat bahwa respon petani terhadap seluruh indikator peran penyuluh sebagai motivator adalah sangat berperan dengan perolehan skor sebesar 108. Hal tersebut menunjukkan bahwa peran penyuluh pertanian lapangan sebagai motivator dirasakan petani telah membantu dalam melakukan pembinaan dan memberikan semangat serta penyuluh pertanian melakukan pendekatanpendekatan personel dengan memberikan perlakuan yang baik dari awal sampai dengan selesai memanen padi organik dengan metode SRI. Penyuluh juga berperan langsung memberikan semangat dan motivasi kepada petani untuk tetap bertahan dan mencintai pekerjaannya sebagai petani.

\section{Penyuluh Sebagai Edukator}

Peran penyuluh sebagai edukator adalah memfasilitasi proses belajar yang dilakukan oleh penyuluh yang bersifat partisipatif dan dialogis. Skor peran penyuluh sebagai edukator terdapat pada Tabel 3 sebagai berikut:

Tabel 3. Kategori Peran Penyuluh Sebagai Edukator

\begin{tabular}{lll}
\hline Edukator & \multicolumn{1}{l}{ Nilai } \\
\hline $\begin{array}{l}\text { Memberikan pelatihan pada } \\
\text { kelompok tani }\end{array}$ & 39 \\
\hline $\begin{array}{l}\text { Memberikan ide / gagasan kepada } \\
\text { petani }\end{array}$ & 39 \\
\hline $\begin{array}{l}\text { Mempraktikkan secara langsung } \\
\text { setelah memberikan ide / gagasan }\end{array}$ & 39 \\
\hline Total Nilai & 117 \\
\hline Kategori & $\begin{array}{l}\text { Sangat } \\
\text { Berperan }\end{array}$ \\
\hline
\end{tabular}

Sumber : Analisis Data Primer, 2019

Berdasarkan Tabel 3, dapat dilihat bahwa respon petani terhadap seluruh indikator peran penyuluh sebagai edukator sangat berperan dengan perolehan skor sebesar 117. Hal tersebut menunjukkan bahwa pada dasarnya upaya penyuluh pertanian dalam menjalankan perannya sudah baik, karena peran penyuluh sebagai edukator yang menyampaikan informasi mencakup inovasi dalam budidaya padi organik dengan metode SRI di kelompok tani Mapan Sejahtera untuk kemajuan petani dalam ushataninya. Selain itu penyuluh berperan dalam melatih keterampilan petani dalam mengembangkan usahataninya.

\section{Peran Penyuluh Sebagai Komunikator}

Peran penyuluh sebagai komunikator dalam kegiatan penyuluhan adalah orang yang tugasnya menyampaikan pesan, apakah itu pesan pembangunan dalam artian yang lebih umum 
ataupun pesan khusus tentang suatu inovasi pertanian untuk mengubah perilaku petani.

Tabel 4. Kategori Peran Penyuluh Sebagai Komunikator

\begin{tabular}{ll}
\hline Komunikator & Nilai \\
\hline $\begin{array}{l}\text { Membantu percepatanarus informasi } \\
\text { pada petani }\end{array}$ & 35 \\
\hline $\begin{array}{l}\text { Membantu petani dalam proses } \\
\text { pengambilan keputusan }\end{array}$ & 39 \\
\hline $\begin{array}{l}\text { Memiliki kemampuan komunikasi } \\
\text { yang baik dengan petani }\end{array}$ & 39 \\
\hline Total Nilai & 113 \\
\hline Kategori & $\begin{array}{l}\text { Sangat } \\
\text { Berperan }\end{array}$ \\
\hline Sumber : Analisis Data Primer, 2019 &
\end{tabular}

Sumber : Analisis Data Primer, 2019

Berdasarkan Tabel 4, dapat diketahui bahwa respon petani terhadap seluruh indikator peran penyuluh sebagai komunikator sangat berperan. Hal ini ditunjukkan dengan perolehan skor sebesar 113. Dari hasil penelitian ini dapat diketahui bahwa pada dasarnya upaya penyuluh pertanian dalam menjalankan perannya sebagai media komunikasi ke petani dari informasiinformasi yang tidak diperoleh oleh petani di dunia luar, penyuluh dalam menyampaikan informasi kepetani dengan metode ceramah dan demonstrasi secara langsung di sawah milik petani yang tergabung dalam kelompok tani Mapan Sejahtera.

Kendala Penyuluh Dalam Penerapan Metode SRI (System of Rice Intensification) Di Kelompok Tani Mapan Sejahtera

Berdasarkan hasil wawancara dengan responden, terdapat beberapa kendala yang dihadapi penyuluh pertanian dalam melakukan aktivitas penyuluhan pada penerapan budidaya padi organik dengan menggunakan metode SRI di Kelompok Tani Mapan Sejahtera Kelurahan Mamburungan Kecamatan Tarakan Timur, meliputi :

1.Partisipasi Petani

Dari hasil wawancara dengan penyuluh pertanian Kelurahan Mamburungan, bahwa kendala yang dihadapi penyuluh adalah partisipasi petani dalam hal ini adalah minat petani yang masih kurang dalam penerapan budidaya padi organik dengan metode SRI, petani masih terfokus pada budidaya padi secara konvensional. Petani masih mempertimbangkan materi atau temuan-temuan baru yang diberikan oleh penyuluh pertanian.

2.Sarana dan Prasarana Penyuluh

Berdasarkan hasil wawancara dengan PPL, sarana dan prasarana yang diperlukan dan menunjang kegiatan penyuluhan tentang budidaya padi organik dengan metode SRI khususnya di Kelompok Tani Mapan Sejahtera, masih sangat minim. Sarana dan prasarana sangat perlu dalam melakukan kegiatan penyuluhan, karena apbila sarana dan prasarana tidak mendukung maka proses kegiatan penyuluhan akan terhambat, seperti alat-alat penunjang (alat peraga serta brosur-brosur yang digunakan dalam kegiatan penyuluhan).

\section{KESIMPULAN}

Kesimpulan penelitian ini adalah peran penyuluh pertanian dalam penerapan budidaya padi organik dengan menggunakan metode SRI (System of Rice Intensification) di Kelompok Tani Mapan Sejahtera Kelurahan Mamburungan Kota Tarakan, dikatagorikan sangat berperan dalam menjalankan tugasnya sebagai fasilitator, motivator, edukator, dan komunikator. Peran penyuluh sebagai fasilitator, diperoleh skor 117 dengan kategori sangat berperan sedangkan peran penyuluh sebagai motivator, diperoleh skor 108 dengan kategori sangat berperan. Peran penyuluh sebagai edukator, diperoleh skor 117 dengan kategori sangat berperan dan peran penyuluh sebagai komunikator, diperoleh 113 dengan kategori sangat berperan.

Kendala penyuluh pertanian lapangan dalam kegiatannya adalah kurangnya partisipasi petani dalam pengembangan budidaya padi organik dengan sistem SRI, petani masih terfokus dengan budidaya padi secara konvensional, sarana dan prasarana dalam melakukan kegiatan penyuluhan masih sangat minim sehingga mengakibatkan proses kegiatan penyuluhan terhambat.

\section{UCAPAN TERIMA KASIH}

Puji serta syukur penulis panjatkan kepada Allah SWT, yang atas Rahman dan Rahiim-Nya, penulis masih diberikan kesehatan dan kemampuan dalam menyelesaikan artikel yang berjudul "Peran Penyuluh Pertanian Dalam Penerapan Budidaya Padi Organik Dengan Metode SRI (System of Rice Intensification) Kelompok Tani Mapan Sejahtera Kelurahan Mamburungan Kota Tarakan". Dalam pelaksanaan penelitian hingga penulisan artikel ini, penulis banyak mendapatkan bantuan dari berbagai pihak. Oleh karena itu, dalam kesempatan kali ini penulis ingin menyampaikan ucapan terimakasih yang sebesar-besarnya kepada seluruh pihak atas tersusunnya artikel ini yang tentunya tidak dapat disebutkan satu persatu. 


\section{DAFTAR PUSTAKA}

IFOAM. 2005. Prinsip-prinsip Pertanian Organik (terjemahan). International Federations of Organic Agriculture Movements. Bonn, Germany.

Hariadi SS. 2011. Dinamika Kelompok Teori dan Aplikasi untuk Analisis Keberhasilan Kelompok Tani Sebagai Unit Belajar, Kerjasama, Produksi, dan Bisnis. Sekolah Pascasarjana Universitas Gajah Mada, Yogyakarta.

Hutagaol MP, Haryati S. 2013. Ekonomi Pangan: Efektivitas Kebijakan Bantuan Langsung Benih Unggul Dan Pupuk Untuk Usahatani Pangan. Jurnal Pangan 22 (1): 11-20.

Kowiyah. 2012. Kemampuan Berpikir Kritis. Jurnal Pendidikan Dasar 3 (5): 175-179.

Mangunwidjaja D, Sailah I. 2009. Pengantar Teknologi Pertanian. Penebar Swadaya, Bogor.

Undang-undang Republik Indonesia Nomor 16 Tahun 2006 tentang Sistem Penyuluhan Pertanian, Perikanan, dan Kehutanan. 